\title{
Effects of large wood on floodplain connectivity in a headwater Mid-Atlantic stream
}

\author{
Tyler A. Keys ${ }^{\mathrm{a}, *}$, Heather Govenor ${ }^{\mathrm{a}}$, C. Nathan Jones ${ }^{\mathrm{c}, \mathrm{d}}$, W. Cully Hession ${ }^{\mathrm{a}}$, Erich T. Hester ${ }^{\mathrm{b}}$, \\ Durelle T. Scott ${ }^{\mathrm{a}}$
}

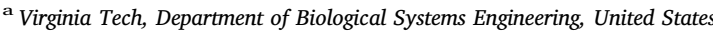

${ }^{\mathrm{b}}$ Virginia Tech, Department of Civil and Environmental Engineering, United States

c Virginia Tech, Department of Forest Resources and Environmental Conservation, United States

d University of Maryland, National Socio-Environmental Synthesis Center, United States

\section{A R T I C L E I N F O}

\section{Keywords:}

Large wood

Floodplains

Hydrodynamic modeling

HEC-RAS

\begin{abstract}
A B S T R A C T
Large wood (LW) plays an essential role in aquatic ecosystem health and function. Traditionally, LW has been removed from streams to minimize localized flooding and increase conveyance efficiency. More recently, LW is often added to streams as a component of stream and river restoration activities. While much research has focused on the role of LW in habitat provisioning, geomorphic stability, and hydraulics at low to medium flows, we know little about the role of LW during storm events. To address this question, we investigated the role of LW on floodplain connectivity along a headwater stream in the Mid-Atlantic region of the United States. Specifically, we conducted two artificial floods, one with and one without LW, and then utilized field measurements in conjunction with hydrodynamic modeling to quantify floodplain connectivity during the experimental floods and to characterize potential management variables for optimized restoration activities. Experimental observations show that the addition of LW increased maximum floodplain inundation extent by $34 \%$, increased floodplain inundation depth by $33 \%$, and decreased maximum thalweg velocity by $10 \%$. Model results demonstrated that different placement of LW along the reach has the potential to increase floodplain flow by up to $40 \%$, with highest flooding potential at cross sections with high longitudinal velocity and shallow depth. Additionally, model simulations show that the effects of LW on floodplain discharge decrease as storm recurrence interval increases, with no measurable impact at a recurrence interval of more than 25 years.
\end{abstract}

\section{Introduction}

Large wood (LW) plays an important, yet undervalued role in river ecosystems. One of the most important functions of LW is its ability to increase floodplain connectivity, the lateral exchange of water and material between rivers or streams and their adjacent floodplains (Harvey and Gooseff, 2015; Covino, 2017). LW plays a crucial role in floodplain connectivity as it decreases longitudinal stream flow velocity (Davidson and Eaton, 2013), increases floodplain inundation (Collins and Montgomery, 2002), and increases transient storage (Mueller Price et al., 2016; Rana et al., 2017). This in turn can provide a variety of ecosystem services such as promoting geomorphic stability/instability (Montgomery et al., 2003), influencing the transport and storage of sediment (Parker et al., 2017), providing habitat for aquatic wildlife (Dolloff and Warren, 2003; Johnson et al., 2003), and enhancing water quality (Krause et al., 2014). While these ecological benefits are well acknowledged, LW can also be hazardous to infrastructure and people
(Wohl et al., 2016). Historically, LW has been removed from streams for the purpose of limiting flood hazards (Wilford et al., 2004), lowering water tables to comply with Federal Emergency Management Agency (FEMA) regulations (Schmocker and Weitbrecht, 2013), and limiting damage to infrastructure such as culverts, roads, and bridges (Lagasse et al., 2012). Thus, management of LW is important and often requires a balance of ensuring infrastructure stability and protection of critical ecosystem services (Ruiz-Villanueva et al., 2016).

The importance of instream LW on fluvial processes has been widely acknowledged and extensively studied over the past 30 years (Abbe and Montgomery, 1996; Jeffries et al., 2003; Sear et al., 2010; Gurnell et al., 2002). LW is useful for restoring streams as it is relatively inexpensive and serves as a natural form of stream restoration and rehabilitation (Kail et al., 2007). As such, LW has widely been used in stream restoration, a multi-billion dollar industry in the U.S. and Europe (Bernhardt et al., 2005; Angelopoulos et al., 2017). Due to the widespread use of LW in stream restoration projects, there is a need to

\footnotetext{
* Corresponding author.

E-mail address: tkeys@vt.edu (T.A. Keys).
} 
improve and optimize the use of LW.

There are currently several critical aspects of LW science that remain unexplored. First, the effects of LW in streams have been studied primarily at baseflow (Matheson et al., 2017). In contrast, little is known about the effects of LW during stormflow, when the majority of solute and sediment transport occurs (Ensign et al., 2006). However, directly measuring the impacts of LW during stormflow is challenging due to the stochastic nature of storm events and difficulty in capturing natural flood pulses. In addition, LW has been studied primarily in the Western U. S. (e.g., Bilby and Ward, 1991; May and Gresswell, 2003; Wohl and Goode, 2008). While these studies have provided valuable insight on LW dynamics, water resources management in this region differs greatly from that of humid regions of the world where water quality is of greater concern than water quantity (Karr and Dudley, 1981). Finally, studies have primarily focused on the transport and deposition of LW (e.g., Dixon and Sear, 2014; Ruiz-Villanueva et al., 2014), treating LW as dynamic system components as opposed to static instream structures. However, LW can also act as more permanent instream structures and affect critical ecological processes such as hyporheic exchange (Hester and Doyle, 2008), nitrate removal (Hester et al., 2016a,b), and habitat provisioning (Johnson et al., 2003). Due to these limitations, the effects of LW on stream flooding dynamics have been largely neglected. The shortage of and need for experimental research on these effects was the primary motivation for our research effort.

The overall goal of this study was to assess the impacts of LW on floodplain connectivity by utilizing experimental field observations and hydraulic modeling of a headwater stream in the US Mid-Atlantic region. Here, we hypothesized that the addition of LW increases floodplain connectivity while decreasing longitudinal velocity in the main channel. Specific research objectives included: 1) quantifying the impact of LW on floodplain inundation extent, depth, and velocity; 2) assessing the impact of LW at varying locations along the reach; and 3) quantifying the influence of LW on floodplain connectivity across a gradient of flood magnitudes. We addressed these objectives by conducting a series of experimental floods along a headwater stream, and then utilized hydrodynamic modeling combined with our field-scale measurements to characterize floodplain connectivity during the experimental floods and across a synthetic flow record. These results both improve our understanding of LW flood dynamics and provide further guidance for the restoration community in the use of LW.

\section{Materials and methods}

\subsection{Study site}

The study site is located in Blacksburg, Virginia at the Virginia Tech Stream Research, Education, and Management (StREAM) Lab (vtstreamlab.weebly.com/) in the Valley and Ridge physiographic province. We selected this location because it is representative of headwater streams. In addition, the StREAM Lab provided an advantageous location for flood experimentation as flood dynamics have been extensively studied there and there are several continuous flow monitoring stations (Jones et al., 2015; Azinheira et al., 2014; Hester et al., 2016a,b; Keys et al., 2016). Within the StREAM Lab, the study was conducted on a 50-m reach of Docs Branch (Fig. 1), a first-order tributary to Stroubles Creek with an average bankfull width of $0.93 \mathrm{~m}$. This specific reach contains an H-flume with discharge measurements, which was used to set upstream boundary conditions. The stream is located at an altitude of $610 \mathrm{~m}$ above mean sea level and has an average slope of 0.01 . The contributing watershed encompasses an area of $1 \mathrm{~km}^{2}$ and is primarily composed of agricultural land use.

\subsection{Flooding experiments}

We conducted three experimental floods over a three-day period (e.g., one flood per day). During each flood, we dammed the stream channel upstream of the study reach by sealing two side-by-side $1.2 \mathrm{~m}$ diameter concrete culverts with a wooden sluice gate and plastic tarp. The experimental floods were then initiated by pulling the sluice gate and releasing the dammed water into the study reach. Prior to releasing the dammed water, ponded depth was measured to ensure that floods were similar in total volume. The initial flood was conducted to prime the system and ensure that floodplain soil moisture conditions were similar for the subsequent experimental floods. The second and third flood events (hereafter flood without LW and flood with LW, respectively) were used to examine the effects of LW on floodplain connectivity. Specifically, the flood without LW was released under normal conditions without wood in the stream, and the flood with LW was released after installing three pieces of LW in the reach (Fig. 1). We collected the three pieces of LW from a nearby upland and placed them horizontally in the stream with the rootwads facing upstream, based on the guidelines from previous research (Rafferty, 2013). All three pieces of LW spanned the stream channel width (Fig. 1b-d), as is generally the case in small streams (Gurnell et al., 2002). Floods were conducted from May 24-May 26, 2016. Using regional curves for non-urban streams in the ridge and Valley Province (Keaton et al., 2005), we found that the 1.5 year flood event for a $1 \mathrm{~km}^{2}$ watershed would be $515 \mathrm{~L} / \mathrm{s}$. This is approximately 9 times greater than peak flows generated in both experimental floods, indicating that the experimental floods are representative of realistic floods that would occur multiple times per year.

At the upstream boundary of the reach, discharge was measured using a $0.9 \mathrm{~m}$ HL-type flume (Brakensiek et al., 1979) and an Onset HOBO Pressure Transducer (PT). Flow measurements from the flume were taken every minute and uploaded to a Campbell CR-1000 data logger. At the downstream end of the reach, flow measurements were taken using a SonTek Argonaut-SW Acoustic Doppler Velocimeter (ADV). Measurements from the ADV were also taken at 1-min intervals and directly uploaded to a field computer. Additionally, three Onset HOBO PTs were placed throughout the floodplain to measure flow depth (Fig. 1).

\subsection{Hydrodynamic modeling}

\subsubsection{Model description}

We used Hydrologic Engineering Center's River Analysis System (HEC-RAS) hydraulic modeling software to model 2-dimensional (2D) surface water hydrodynamics for the stream reach. HEC-RAS is commonly used for hydraulic modeling due to its strong computational abilities, quick processing time, and free availability through the U.S. Army Corps of Engineers. The recent addition of 2D modeling to HECRAS makes it an appealing option for floodplain modeling studies such as the one presented here. Specifically, HEC-RAS numerically solves the 2D Saint-Venant equations for conservation of mass (Eq. (1)), conservation of momentum in the $\mathrm{x}$ direction (Eq. (2)), and conservation of momentum in the y direction (Eq. (3)):

$$
\begin{aligned}
& \frac{\partial \mathrm{H}}{\partial \mathrm{t}}+\frac{\partial\left(\mathrm{h} v_{x}\right)}{\partial \mathrm{x}}+\frac{\partial\left(\mathrm{h} v_{y}\right)}{\partial \mathrm{y}}=0 \\
& \frac{\partial v_{x}}{\partial \mathrm{t}}+v_{x} \frac{\partial v_{x}}{\partial \mathrm{x}}+g \frac{\partial \mathrm{H}}{\partial \mathrm{x}}+\mathrm{g}\left(\mathrm{S}_{f}-\mathrm{S}_{0}\right)=0 \\
& \frac{\partial v_{y}}{\partial \mathrm{t}}+v_{y} \frac{\partial v_{y}}{\partial \mathrm{y}}+g \frac{\partial \mathrm{H}}{\partial \mathrm{y}}+g\left(\mathrm{~S}_{f}-S_{0}\right)=0
\end{aligned}
$$

where $\mathrm{H}$ is the water surface elevation, $\mathrm{h}$ is hydraulic head, $v_{x}$ is velocity in the downstream direction, $v_{y}$ is velocity in the transverse direction, $g$ is acceleration due to gravity, $S_{\mathrm{f}}$ is the energy slope, and $S_{0}$ is the channel slope. The Saint Venant Equations (Eqs. (1)-(3)) are numerically solved using finite volume approximations discretized with respect to time and space. HEC-RAS can solve the full Saint-Venant equations or the diffusive wave approximation of the Saint-Venant 

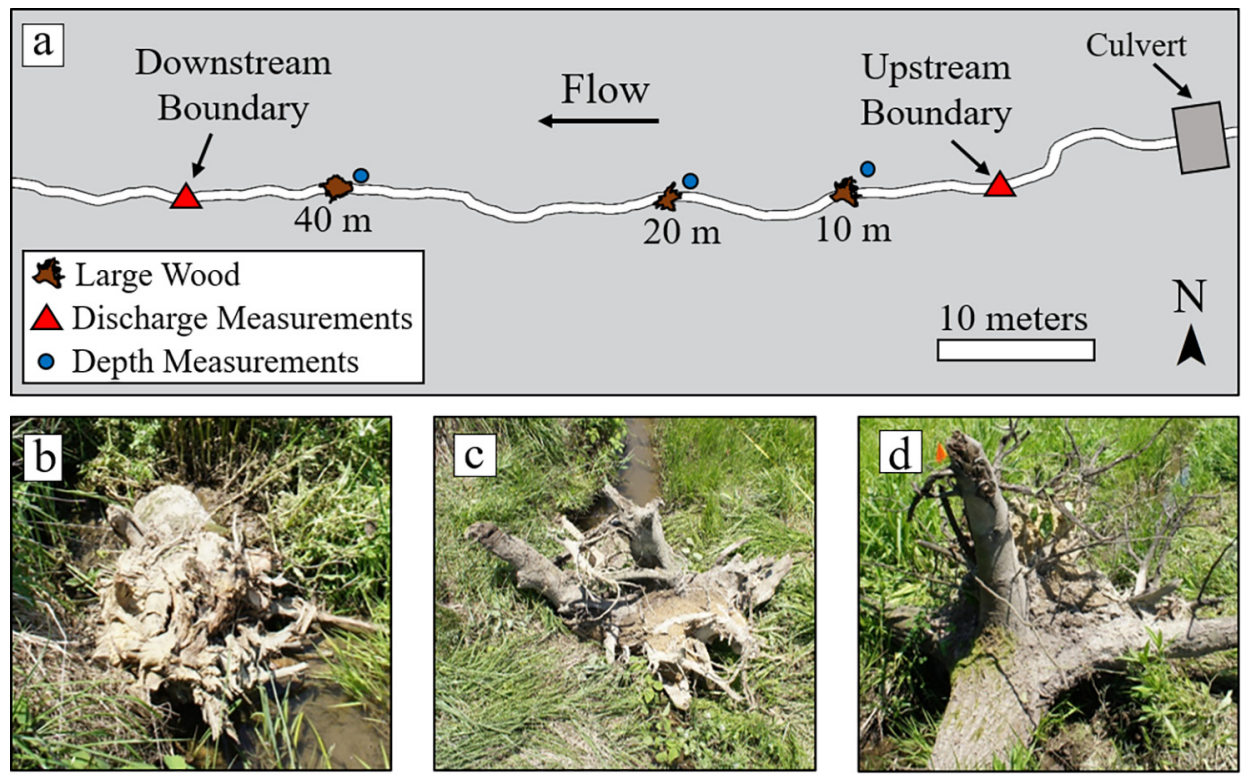

Fig. 1. a) Map of the experimental setup and b-d) the three pieces of LW used in the study.

Equations. When the diffusive wave approach is selected, the first and second terms on the left side of Eqs. (2) and (3) are not used.

We chose to use the 2D diffusive wave routing approach due to its computational speed and model stability. The diffusive wave simplification is a common assumption used in $2 \mathrm{D}$ hydrodynamic modeling of rivers as it assumes that pressure and slope are an order of magnitude greater than local and convective acceleration terms and thus these terms can be ignored (Henderson, 1966). We found that the full SaintVenant and diffusive wave approaches produced similar results, but the diffusive wave technique was approximately 20 times faster and resulted in better model stability. This observation has been noted in previous research (Horritt and Bates, 2001), and studies have successfully employed diffusive wave approximations for 2D modeling of flood events (e.g., Quiroga et al., 2016).

\subsubsection{Model parameterization}

We utilized topography and streamflow data to parameterize the model. Reach topography and stream channel bathymetry were surveyed using a real-time kinematic geographic positioning system (RTKGPS, Topcon GR-3). Prior to the flood events, we surveyed 1088 elevation data points within the stream channel and across the floodplain to capture channel bathymetry and micro-topography of the $50 \mathrm{~m}$ long reach. These elevation data points were then used to develop a triangulated irregular network and produce a seamless digital elevation model (DEM) of the stream and adjacent floodplain. We then imported the DEM of the reach into HEC-RAS for hydraulic analysis. A 2D flow area of $877 \mathrm{~m}^{2}$ was created around the border of the DEM to ensure that the entire reach was analyzed. Grid discretization of $0.5 \mathrm{~m}$ by $0.5 \mathrm{~m}$, similar to the density of surveyed GPS points, was used to balance model accuracy and computational time. This resulted in a computational mesh containing 3853 cells across the flow area. Bank lines were enforced within the mesh to ensure that the stream channel was properly discretized. Three cross sections were incorporated into the mesh and used to model LW locations along the stream.

Boundary conditions were established using discharge data from the flume measured at the upstream boundary and normal depth at the downstream boundary of the reach. A computational time step of $5 \mathrm{~s}$ was used to meet the Courant condition $(\Delta t>\Delta x / c)$ for model stability (Pappenberger et al., 2005), where $\Delta t$ is the computational time step, $\Delta \mathrm{x}$ is the space step and $\mathrm{c}$ is the speed of the flood wave. Alternatively, the HEC-RAS dam breach user manual (Brunner, 2014) suggests using a computations time step of $\Delta \mathrm{t}<\operatorname{Tr} / 20$, where $\operatorname{Tr}$ is the time of rise of the flood hydrograph. This approach would yield a time step of $6 \mathrm{~s}$, and therefore, $5 \mathrm{~s}$ was still an appropriate selection for the computational time step. We assumed initial Manning's $n$ values of 0.05 and 0.1 in the channel and floodplain, respectively based on estimates from similar headwater streams (Jarrett, 1984; Marcus et al., 1992).

\subsubsection{Model calibration/validation}

The flood without LW was calibrated by comparing modeled outflows with flow measurements from the ADV. To calibrate the model, the Manning's $n$ values for the channel and floodplain were adjusted to minimize error and improve the overall model fit. For the model of the flood with LW, Manning's $n$ values were kept at the same calibrated values and modeled LW geometry was adjusted to improve the model fit. The LW cross sections were modeled as weir embankments with orifices randomly placed across the face of the embankment. Previous studies have utilized similar simple techniques for modeling LW in streams (e.g., Hafs et al., 2014), and we found it to be a simple approach for modeling instream LW. To validate the model, modeled floodplain stage values were compared to measured stage values. To evaluate error and calibrate/validate the models, we used coefficient of determination $\left(\mathrm{R}^{2}\right)$, normalized root mean square error (NRMSE), and Nash-Sutcliffe efficiency (NSE).

\subsection{Modeling alternative scenarios}

\subsubsection{LW placement}

To assess spatial variability along the reach, floodplain discharge was modeled by simulating a single piece of LW at different locations longitudinally along the reach. Overall, 50 simulations were conducted, each with a single LW cross section located at $1 \mathrm{~m}$ intervals along the reach. Floodplain discharge $\left(\mathrm{Q}_{\mathrm{FP}}\right)$ was calculated in HEC-RAS as the total volume of water moving laterally across the stream banks and into the floodplain per unit time. Total discharge $\left(Q_{t o t}\right)$ for each cross section was calculated as the total volume of water moving longitudinally across the given cross section per unit time. Ratios of $\mathrm{Q}_{\mathrm{FP}}$ to $\mathrm{Q}_{\text {tot }}$ were then calculated for each cross section both with and without LW incorporated. To better understand the variability of $\mathrm{Q}_{\mathrm{FP}} / \mathrm{Q}_{\text {tot }}$ values along the reach, we also analyzed maximum velocity, water depth, channel slope, width to depth (W:D) ratio, and channel sinuosity for each cross section. 


\subsubsection{Flood magnitude}

Alternative storm events were modeled to determine the impacts of LW across varying flow regimes. To simulate various storm events, we developed a 1000-year synthetic rainfall distribution by applying a Bartlett-Lewis model (Rodriguez-Iturbe et al., 1987) to over 70 years of meteorological data measured at the Virginia Tech Montgomery Executive Airport, located $\sim 1 \mathrm{~km}$ from the study reach. The rainfall data were disaggregated to a sub-hourly timescale with $\mathrm{R}$ statistical software (R Development Core Team, 2017) using the HyetosMinute package (Kossieris et al., 2016). An exceedance curve was calculated from the 1000-year synthetic rainfall dataset and used to estimate 1, 2, 3, 5, 10, $15,25,50,100,250,500$, and 1000-year storms events for the same duration. Runoff from the selected storm events was calculated using the Natural Resources Conservation Service (NRCS) curve number unit hydrograph approach (Arnold et al., 1998). Runoff hydrographs were then used as inflow hydrographs in HEC-RAS, and the reach was modeled with and without LW present. This allowed us to quantify the impact that LW would have on flooding caused by a wide range of storm events.

\section{Results}

\subsection{Experimental flooding}

We observed relatively similar inflow (upstream boundary) hydrographs between the two experimental floods. Peak discharge values at the upstream boundary of the reach were $55.8 \mathrm{~L} / \mathrm{s}$ and $54.8 \mathrm{~L} / \mathrm{s}$ for the flood without LW and the flood with LW, respectively (Fig. 2a). Outflow (downstream boundary) hydrographs showed evidence of a dampened peak discharge and delayed time to peak discharge. Downstream peak discharge for the flood without wood was $53.0 \mathrm{~L} / \mathrm{s}$ occurring $3 \mathrm{~min}$ after the upstream peak discharge (Fig. 2b). For the flood with wood, peak discharge at the downstream boundary was $48.7 \mathrm{~L} / \mathrm{s}$ occurring $4 \mathrm{~min}$ after the upstream peak discharge (Fig. 2c).

The addition of LW also increased floodplain stage and inundation duration at all three LW cross sections (Table 1; Fig. 3a). Average inundation duration at the three LW cross sections was $14 \mathrm{~min}$ for the flood without LW and $18.7 \mathrm{~min}$ for the flood with LW. Average maximum water depth measured at the three LW cross sections was $8 \mathrm{~cm}$ for the flood without LW and $10.8 \mathrm{~cm}$ for the flood with LW. Additionally, stage-discharge hysteresis plots illustrate that the addition of LW increased the total area within the hysteresis loops for all three cross sections (Fig. 3b). The greater area within the hysteresis loops indicates that there was a greater difference between the rising and falling limbs of the hydrographs, and thus LW increased the floodplain residence time at each of the three LW cross sections. Additionally, all of the hysteresis loops followed a counter-clockwise direction, indicating that floodplain stage was greater during the falling limb of the flood hydrograph.

\subsection{Model fit}

Manning's $n$ values of 0.06 within the channel and 0.1 on the floodplain yielded the best fit for the flood without LW and were used for model simulations. At the downstream boundary, modeled and observed results from the flood without LW produced an $\mathrm{R}^{2}$ of 0.88 , an NRMSE of $8.9 \%$, and a NSE of 0.91 , while calibration of the flood with LW produced an $\mathrm{R}^{2}$ of 0.89 , and NRMSE of $9.4 \%$, and an NSE of 0.92 . Floodplain measurements and modeled depths produced an average $\mathrm{R}^{2}$ of 0.83 , NRMSE of $15.9 \%$, and NSE of 0.77 for the flood without LW and an average $\mathrm{R}^{2}$ of 0.82 , NRMSE of $14.6 \%$, and NSE of 0.8 for the flood with LW. A summary of the calibration and validation statistics for each location are shown in Table 2. a)

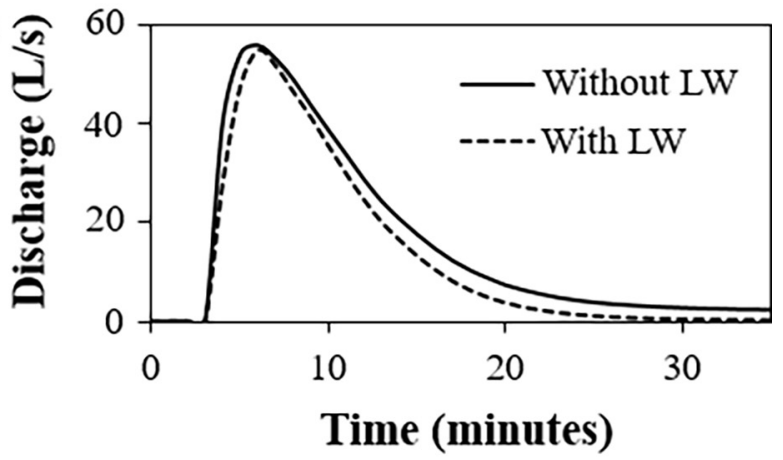

b)
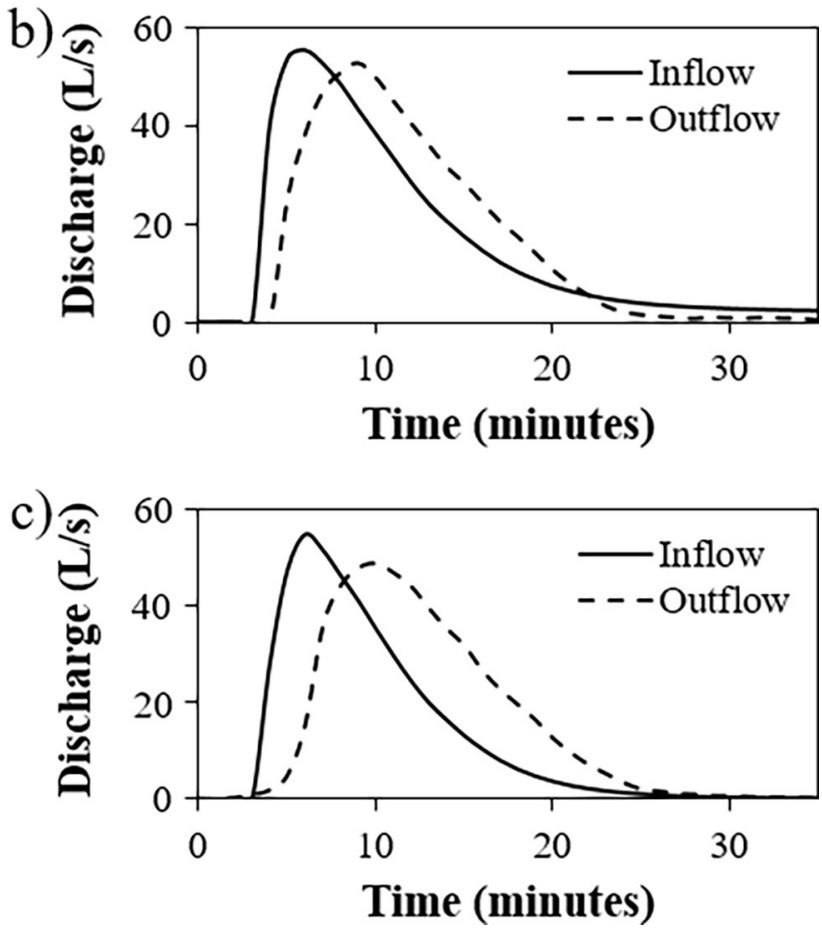

Fig. 2. a) Hydrographs of inflow to the study reach for both floods, b) Upstream and downstream hydrographs for the first flood without LW in the channel, and c) Upstream and downstream hydrographs for the second flood with LW in the channel.

Table 1

Summary of inundation duration and maximum depth at each of the three LW cross sections.

\begin{tabular}{lllll}
\hline Location & Without LW & \multicolumn{3}{c}{ With LW } \\
\cline { 2 - 5 } & $\begin{array}{l}\text { Inundation } \\
\text { Duration (min) }\end{array}$ & $\begin{array}{l}\text { Maximum } \\
\text { Depth (cm) }\end{array}$ & $\begin{array}{l}\text { Inundation } \\
\text { Duration (min) }\end{array}$ & $\begin{array}{l}\text { Maximum } \\
\text { Depth (cm) }\end{array}$ \\
\hline XS1 (10 m) & 9 & 4.5 & 14 & 5.8 \\
XS2 (20 m) & 13 & 7.5 & 14 & 10.0 \\
XS3 (40 m) & 20 & 12.0 & 28 & 16.5 \\
\hline
\end{tabular}

\subsection{Simulation of experimental floods}

Across the reach, maximum modeled inundation surface area was $265 \mathrm{~m}^{2}$ during the flood without LW and $356 \mathrm{~m}^{2}$ during the flood with LW (Fig. 4). Maximum modeled water depth in the thalweg was $0.48 \mathrm{~m}$ during the flood without LW and $0.50 \mathrm{~m}$ during the flood with LW. Maximum modeled water depth in the floodplain was $0.12 \mathrm{~m}$ during the flood without LW and $0.16 \mathrm{~m}$ during the flood with LW. The addition of LW to the channel increased modeled floodplain inundation duration at all three LW cross sections. 
a)
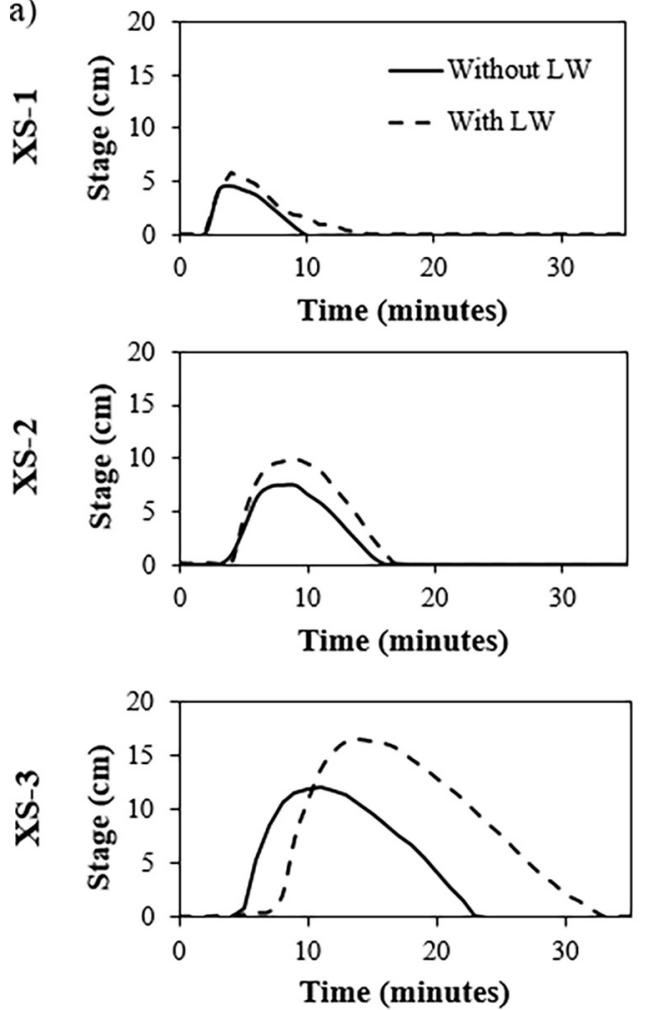
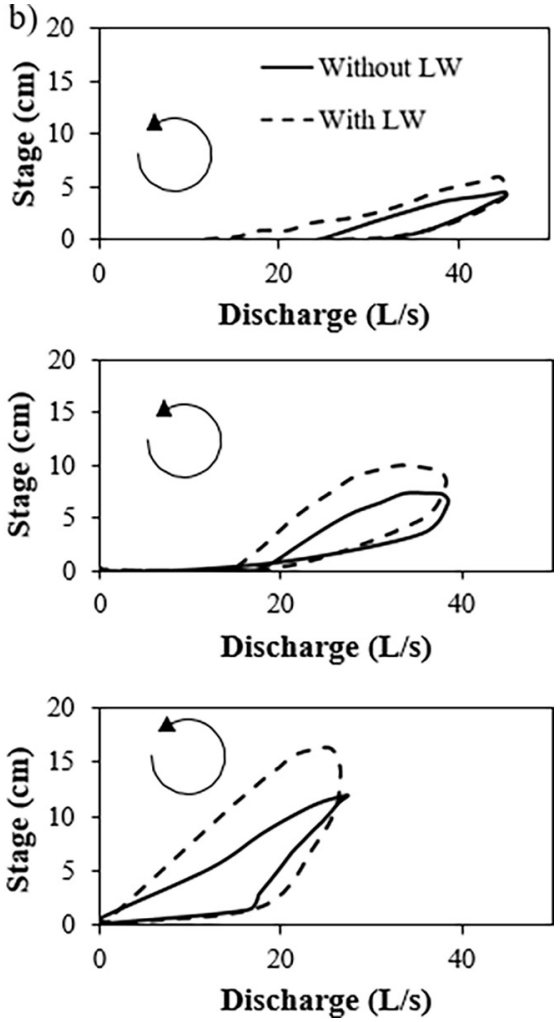

Fig. 3. a) Stage hydrographs at each of the LW cross sections and b) Stage-Discharge hysteresis at each of the LW cross sections.

Table 2

Statistics from calibration of both floods at the downstream boundary and validation at three LW cross sections.

\begin{tabular}{lllllll}
\hline \multirow{2}{*}{ Location } & \multicolumn{2}{l}{ Without LW } & \multicolumn{4}{l}{ With LW } \\
\cline { 2 - 7 } & $\mathrm{R}^{2}$ & NRMSE (\%) & NSE & $\mathrm{R}^{2}$ & NRMSE (\%) & NSE \\
\hline Downstream & 0.88 & 8.9 & 0.91 & 0.89 & 9.4 & 0.92 \\
XS1 (10 m) & 0.88 & 13.8 & 0.74 & 0.85 & 13.1 & 0.80 \\
XS2 (20 m) & 0.83 & 15.2 & 0.80 & 0.89 & 11.5 & 0.88 \\
XS3 (40 m) & 0.79 & 18.6 & 0.76 & 0.71 & 19.2 & 0.72 \\
\hline
\end{tabular}

Velocity dynamics for the reach also varied between the flood without LW and the flood with LW (Fig. 5). During the flood without $\mathrm{LW}$, velocity was highest in the stream channel and lowest in the floodplain. Velocity in the flood with LW was fairly uniform across the reach with the lowest values along the edge of the floodplain and highest values in the stream channel immediately downstream of the
LW cross sections. Maximum water velocity in the thalweg was $0.92 \mathrm{~m} /$ s during the flood without LW and $0.83 \mathrm{~m} / \mathrm{s}$ during the flood with LW. Maximum water velocity in the floodplain increased from $0.30 \mathrm{~m} / \mathrm{s}$ during the flood without LW to $0.66 \mathrm{~m} / \mathrm{s}$ during the flood with $\mathrm{LW}$.

\subsection{Alternative scenario model simulations}

\subsubsection{Location of $L W$}

Variation in the location of LW placement along the stream affected the magnitude and spatial distribution of hydrologic exchange between the stream channel and floodplain (Fig. 6a). The presence of LW in the channel consistently increased floodplain connectivity ( $\mathrm{p}<0.0001$ ), with an average cross-sectional $\mathrm{Q}_{\mathrm{FP}} / \mathrm{Q}_{\text {tot }}$ value of $16.6 \%$ for the flood without LW and $32.3 \%$ for the flood with LW. Maximum simulated $\mathrm{Q}_{\mathrm{FP}} /$ $\mathrm{Q}_{\text {tot }}$ for the flood without LW occurred $28 \mathrm{~m}$ downstream of the inflow and $25 \mathrm{~m}$ downstream of the inflow for the flood with $\mathrm{LW}$. The average difference between the two floods was $15.6 \%$ with the maximum difference occurring $18 \mathrm{~m}$ downstream of the upper boundary. When

a)
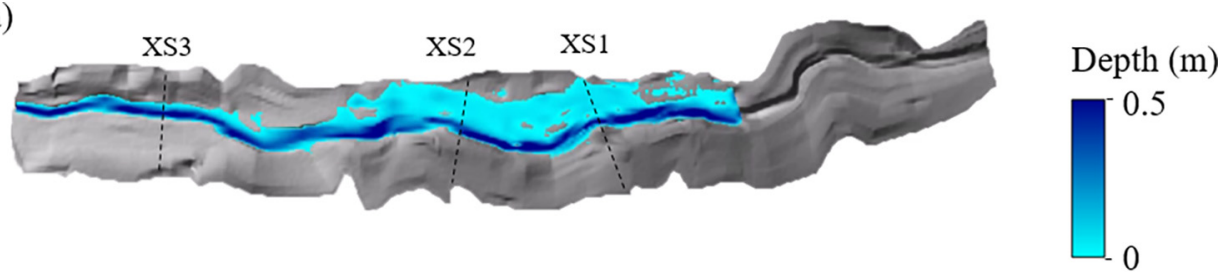

b)
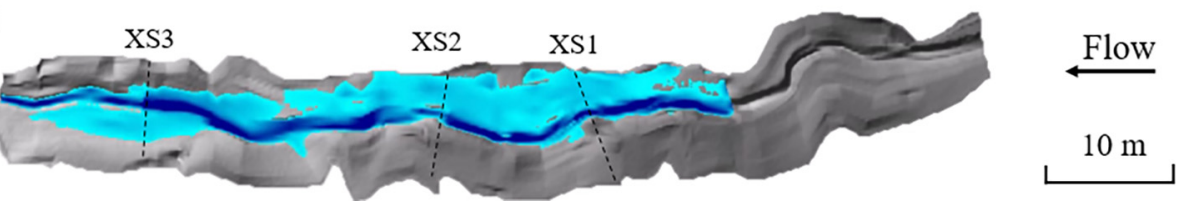

Fig. 4. Planform view of modeled maximum floodplain inundation extent and depth along the reach for a) the flood without LW in the channel and b) the flood with LW in the channel. 
a)

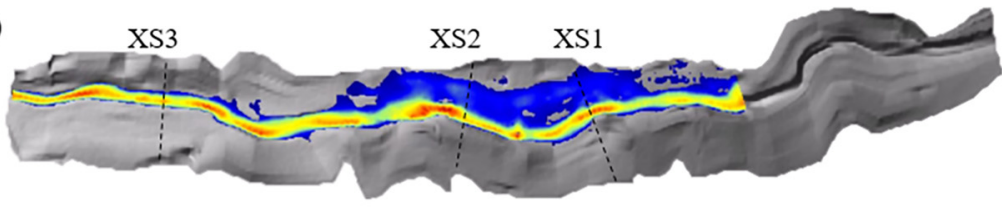

b)

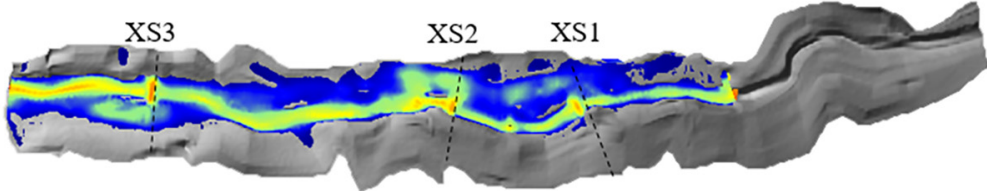

Velocity

$(\mathrm{m} / \mathrm{s})$

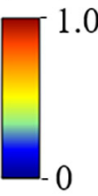

Flow

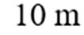

Fig. 5. Planform view of maximum velocity along the reach for a) the flood without LW in the channel and b) the flood with LW in the channel.

simulating the location of LW along the reach, geomorphic characteristics of the stream (i.e., channel slope, W:D ratio, and channel sinuosity) all had very little impact $\left(\mathrm{R}^{2}<0.03\right)$ on flooding dynamics. Modeled floodplain connectivity increased the most when LW was placed in relatively shallow portions of the reach or in places where water was moving fast. Channel velocity and water depth at each cross section without LW in the channel were correlated with $\Delta \mathrm{Q}_{\mathrm{FP}} / \mathrm{Q}_{\text {tot }}$, the floodplain discharge difference between simulations with and without LW. Specifically, thalweg velocity and water depth compared with $\Delta \mathrm{Q}_{\mathrm{FP}} / \mathrm{Q}_{\text {tot }}$ produced $\mathrm{R}^{2}$ values of 0.62 and 0.46 , respectively (Fig. $6 \mathrm{~b}$ and c).

\subsubsection{Flood magnitude}

The addition of $\mathrm{LW}$ increased $\mathrm{Q}_{\mathrm{FP}} / \mathrm{Q}_{\mathrm{tot}}$ for storm events of different magnitudes. Across the range of hypothetical storm events, values of $\mathrm{Q}_{\mathrm{FP}} / \mathrm{Q}_{\text {tot }}$ ranged from $14.8 \%$ to $88.3 \%$ without incorporating $\mathrm{LW}$, while values ranged from $42.7 \%$ to $88.3 \%$ when incorporating LW. However, as the magnitude and recurrence interval of the storm event increased, the percent difference in $\mathrm{Q}_{\mathrm{FP}} / \mathrm{Q}_{\mathrm{tot}}$ decreased, with values converging at

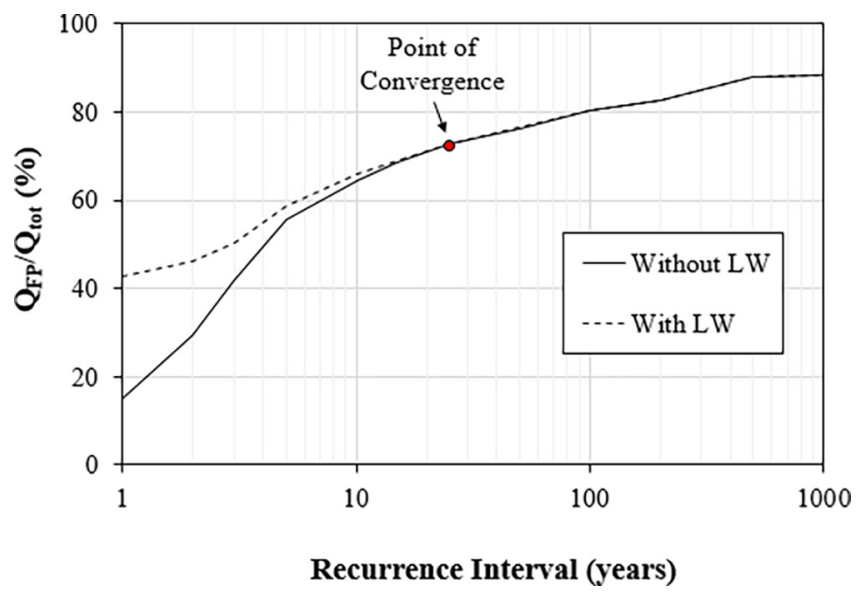

Fig. 7. $\mathrm{Q}_{\mathrm{FP}} / \mathrm{Q}_{\mathrm{tot}}$ vs recurrence interval for a range of modeled storm events. $\mathrm{A}$ convergence point was reached at a recurrence interval of 25 years.

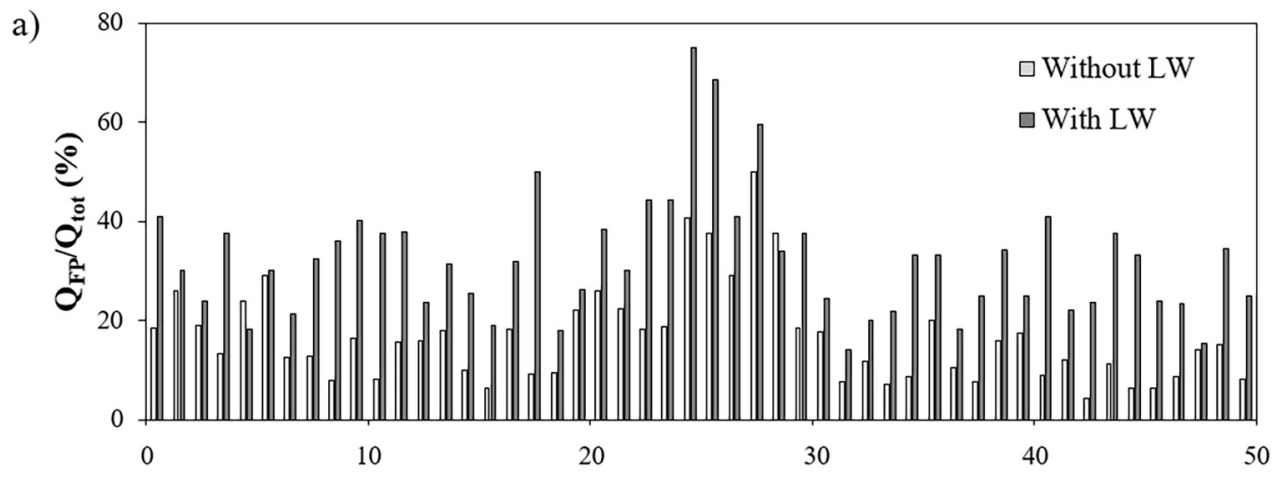

Distance along reach (m)
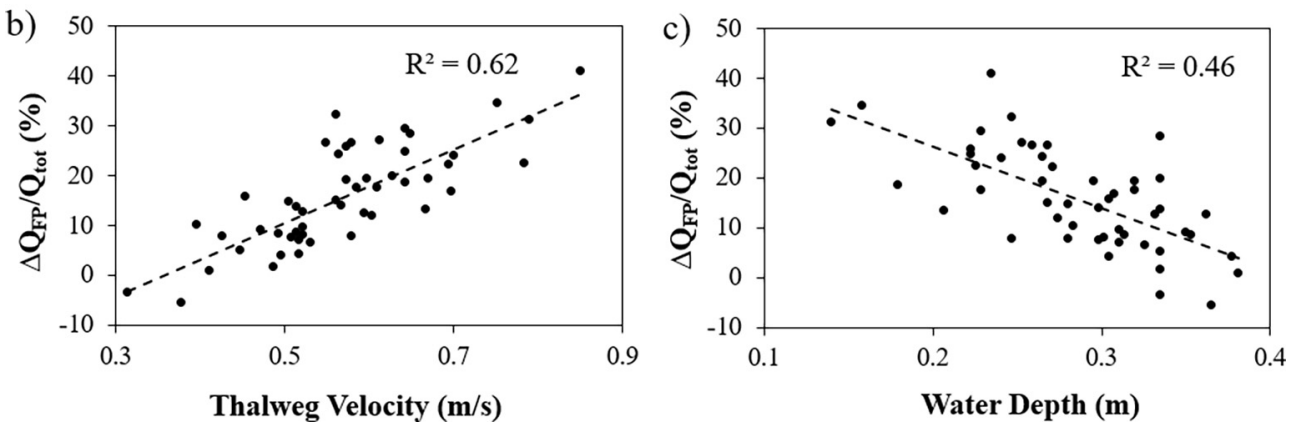

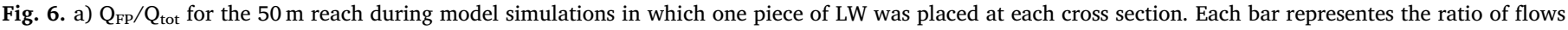
during one simulation, b) $\Delta \mathrm{Q}_{\mathrm{FP}} / \mathrm{Q}_{\text {tot }}$ vs thalweg velocity for each cross section, and c) $\Delta \mathrm{Q}_{\mathrm{FP}} / \mathrm{Q}_{\text {tot }}$ vs thalweg water depth for each cross section. 
an approximately 25-yr recurrence interval (Fig. 7). For example, the addition of LW increased $\mathrm{Q}_{\mathrm{FP}} / \mathrm{Q}_{\text {tot }}$ by $28 \%$ for a 1 -yr storm event, $16 \%$ for a 2 -yr storm event, but only $3 \%$ for a 5 -yr storm event.

\section{Discussion}

\subsection{Impacts of $L W$ on floodplain connectivity}

As anticipated, addition of LW to the stream channel increased inundation extent, depth, duration, and floodplain discharge for the entire reach. Additionally, LW decreased longitudinal flow velocity and increased lateral flow velocity by diverting water onto the floodplain. These findings support the hypothesis that LW increases overall connectivity between the main channel and adjacent floodplain of small, headwater streams and agree with previous research on the hydraulic effects of LW in streams (e.g., Wohl, 2013). Additionally, these findings are consistent with the converse notion that removing LW from streams increases conveyance efficiency and decreases localized flooding, the rationale for removing LW from streams over the past century. Unlike previous research though, this study provides insight on LW flooding dynamics under differing placement strategies and across various flow regimes. In addition, out study took advantage of a controlled flood, thereby allowing us to conduct detailed spatial and temporal measurements that would be extremely difficult during a natural flood.

Model simulations indicate that varying placement strategies would affect the flooding dynamics within the floodplain at different locations along the stream. Specifically, channel velocity and water depth were found to be the most important factors controlling flooding along the reach. For example, the channel has high velocity and shallow depth at the cross section with the greatest potential for flood enhancement by LW (27 $\mathrm{m}$ downstream of the upper boundary in the current study). Placement of LW at this cross section would also create the largest increase in $\mathrm{Q}_{\mathrm{FP}} / \mathrm{Q}_{\text {tot }}$ due to the diversion of fast flowing water onto the floodplain. On the contrary, cross sections with low velocity and greater water depth have the lowest flooding potential (e.g., 5-6 $\mathrm{m}$ downstream of the upper boundary in the current study). These findings agree with previous studies (e.g., Curran and Wohl, 2003), which suggest that LW creates greater flood potential in steeper channels. Thus, knowing the longitudinal velocity (i.e., the velocity head) and water depth can provide a rough estimate of flooding potential along a reach. However, a number of additional characteristics such as roughness, soil hydraulic conductivity, and floodplain geometry could also affect the flooding potential at a given cross section (Darby, 1999; Bates and De Roo, 2000; Hession and Curran, 2013). Thus, the effects of LW on floodplain discharge dynamics is highly site dependent and likely depends on multiple variables.

Simulations of storm events with varying return intervals showed that the impact of LW on floodplain connectivity decreased as recurrence interval increased. At a recurrence interval of 25 years or greater, LW did not have any impact on flooding dynamics. Specifically, results showed that once floodplain flow made up $\sim 70 \%$ of total flow (at a return interval of $\sim 25$ years), the effects of LW were negligible. Intuitively, the effects of LW on flooding decrease as flood magnitude increases because once a channel reaches bankfull flow, lateral flooding caused by LW is no longer the primary mechanism controlling floodplain flow. This is consistent with previous studies examining the effects of instream structures on hyporheic exchange (Hester and Doyle, 2008; Crispell and Endreny, 2009; Azinheira et al., 2014). Overall, results indicate that differing placement strategies and flow regimes can influence the degree to which LW influences floodplain connectivity.

\subsection{Implications for nutrient and sediment management}

Here, we propose that the addition of LW to headwater, agricultural streams can serve as a best management practice (BMP) to improve downstream water quality. Nitrogen $(\mathrm{N})$ and phosphorus $(\mathrm{P})$ are of particular interest as increased loading of these nutrients to surface water bodies is the primary cause of worldwide eutrophication (e.g., Vitousek et al., 1997). Inputs of inorganic $\mathrm{N}$ come largely from agricultural areas drained by headwater streams (Mulholland et al., 2008). While much work has focused on incorporating forested riparian buffer strips into these areas, many of these watersheds still do not supply fallen timber to provide a sustainable budget for LW (Soulsby et al., 2017). In many floodplain systems, biogeochemical processing is limited by the amount of solute transported into floodplains (Forshay and Stanley 2005; Noe and Hupp 2009; Jones et al., 2014; Scott et al., 2014; Jones et al., 2015). Adding LW to streams could increase biogeochemical processing through increased floodplain connectivity of solutes like $\mathrm{N}$, thus enhancing downstream water quality.

Increased floodplain connectivity created by adding LW to stream channels also has implications for both $\mathrm{P}$ and sediment management. Similar to N, the majority of $\mathrm{P}$ and sediment loading comes from excess runoff, particularly from headwater streams with limited BMPs (McFarland and Hauck, 1999). Adding LW to a stream channel can slow down the transport of sediment as well as the transport of $\mathrm{P}$, which is often adsorbed to and transported by sediment (Records et al., 2016). However, as sediment settles within the channel, P can solubilize and be exported as soluble reactive P (Jones et al., 2015). Similarly, N can change forms through mineralization and nitrification depending on other factors such as the amount of available organic matter (McMillan et al., 2010). Additionally, in systems with a high sediment load, LW could enhance trapping of sediment in the stream channel and eventually cause the LW to become buried. Thus, nutrient and sediment dynamics are often site-specific and fairly complex in nature. While LW can be a tool for nutrient and sediment management, the addition of LW to streams must be carefully considered from a holistic point of view as the removal of one pollutant can lead to unexpected and undesired side effects.

\subsection{Future work and limitations}

\subsubsection{Spatially distributed roughness estimates}

This study did not take into account the spatial variability of the longitudinal or lateral Manning's $n$ value. While we were able to use different $n$ values for the main channel and floodplain, this does not give an accurate representation of the spatial heterogeneity of roughness across the study reach. Even at the reach scale, roughness can vary substantially and affect connectivity (Hession and Curran, 2013). Future modeling studies should use a spatially distributed Manning's $n$ value to get a more accurate representation of channel and floodplain roughness. This can be done using aerial lidar (Straatsma and Baptist, 2008; Abu-Aly et al., 2014) or structure-from-motion photogrammetry (Smith et al., 2004). While outside the scope of this research, inclusion of such a spatially-varying roughness coefficient would create a more accurate representation of the river corridor and improve the overall model fit.

\subsubsection{Long term hydrogeomorphology}

Future work should also examine the long-term effects of LW on stream hydrogeomorphology. The effects of LW on flooding have been largely overlooked in the field of fluvial geomorphology but studies suggests that these effects are actually a critical component of stream geomorphology (Gurnell et al., 2002). A number of studies have emphasized the important role that LW plays in morphological processes (e.g., Piégay and Gurnell, 1997; Gurnell, 2012), but few studies have explicitly examined the role of LW on flooding, a key component of fluvial geomorphology (Woltemade, 1994). Additionally, long-term effects are often difficult to examine due to the monetary cost of longterm stream monitoring and small scope of most stream restoration projects. However, the availability of emerging technologies such as freely-available, high-resolution remote sensing data allows for more frequent and accurate monitoring of streams. This type of monitoring is 
crucial for understanding the long-term effects of LW on the geomorphology of streams and rivers.

\subsubsection{Recreating beaver dams}

A unique aspect of this study that could be valuable for future studies is simulating and recreating beaver dams. Beaver dams provide ecological benefits by increasing floodplain connectivity (Westbrook et al., 2006), increasing hyporheic connectivity (Briggs et al., 2013), and serving as a sink of reactive solutes during periods of high flow (Wegener et al., 2017). Once highly ubiquitous across the landscape, beaver dams have been largely removed as a result of anthropogenic activities (Pollock et al., 2014). The loss of beaver dams over the years has resulted in an increase of sediment and pollutant transport (Levine and Meyer, 2014). However, recent studies have highlighted the potential for restoring streams with recreated beaver dam analogs (Pollock et al., 2014; Bouwes et al., 2016), which are structures that can be designed to mimic natural beaver dams. Similar to beaver dam analogs, LW has the potential to reestablish stream ecosystem health by restoring the natural flow regime. Adding LW to streams is a simple, cost-effective technique that can provide ecological benefits that are similar to those of beaver dam analogs.

\section{Conclusions}

There is a need for a better understanding of the impacts of LW on headwater stream floodplain dynamics, particularly in the Mid-Atlantic region of the U.S. Our research addressed this issue by examining the impacts that LW has on floodplain connectivity in a headwater MidAtlantic stream utilizing a controlled, experimental flood event. Results indicate that the addition of LW to small, headwater streams increases floodplain inundation extent, depth, and discharge, and decreases longitudinal stream velocity. Additionally, we found that placement strategies and varying flow regimes could influence the role that LW plays in floodplain hydrodynamics. These findings confirm the overall hypothesis that LW plays an important role in floodplain connectivity of headwater streams. Overall, this work provides insight into the impacts of LW on flooding dynamics during storm events.

\section{Acknowledgements}

The authors would like to thank Dumitru Branisteanu and Laura Lehmann for assisting with the experimental setup as well as Daniel Frisbee, Allison Guzman, and Rachel Molloy for their assistance with surveying. This research did not receive any specific grant from funding agencies in the public, commercial, or not-for-profit sectors.

\section{Appendix A. Supplementary data}

Supplementary data associated with this article can be found, in the online version, at http://dx.doi.org/10.1016/j.ecoleng.2018.05.007.

\section{References}

Abbe, T.B., Montgomery, D.R., 1996. Large woody debris jams, channel hydraulics and habitat formation in large rivers. Regul. Rivers Res. Manage. 12 (23), 201-221.

Abu-Aly, T.R., Pasternack, G.B., Wyrick, J.R., Barker, R., Massa, D., Johnson, T., 2014. Effects of LiDAR-derived, spatially distributed vegetation roughness on two-dimensional hydraulics in a gravel-cobble river at flows of 0.2 to 20 times bankfull. Geomorphology 206, 468-482. http://dx.doi.org/10.1016/j.geomorph.2013.10.017.

Angelopoulos, N.V., Cowx, I.G., Buijse, A.D., 2017. Integrated planning framework for successful river restoration projects: upscaling lessons learnt from European case studies. Environ. Sci. Policy 76, 12-22. http://dx.doi.org/10.1016/j.envsci.2017.06. 005.

Arnold, J.G., Srinivasan, R., Muttiah, R.S., Williams, J.R., 1998. Large area hydrologic modeling and assessment part I: model development. J. Am. Water Resour. Assoc. 34 (1), 73-89. http://dx.doi.org/10.1111/j.1752-1688.1998.tb05961.x.

Azinheira, D.L., Scott, D.T., Hession, W., Hester, E.T., 2014. Comparison of effects of inset floodplains and hyporheic exchange induced by in-stream structures on solute retention. Water Resour. Res. 50 (7), 6168-6190. http://dx.doi.org/10.1002/
2013WR014400.

Bates, P.D., De Roo, A.P.J., 2000. A simple raster-based model for flood inundation simulation. J. Hydrol. 236 (1), 54-77. http://dx.doi.org/10.1016/S0022-1694(00) 00278-X.

Bernhardt, E.S., Palmer, M.A., Allan, J.D., Alexander, G., Barnas, K., Brooks, S., et al., 2005. Synthesizing US river restoration efforts. Science 308 (5722), 636-637. http:// dx.doi.org/10.1126/science.1109769.

Bilby, R.E., Ward, J.W., 1991. Characteristics and function of large woody debris in streams draining old-growth, clear-cut, and second-growth forests in southwestern Washington. Can. J. Fish. Aquat. Sci. 48 (12), 2499-2508. http://dx.doi.org/10. 1139/f91-291.

Bouwes, N., Weber, N., Jordan, C.E., Saunders, W.C., Tattam, I.A., Volk, C., et al., 2016 Ecosystem experiment reveals benefits of natural and simulated beaver dams to a threatened population of steelhead (Oncorhynchus mykiss). Sci. Rep. 6, 28581. http://dx.doi.org/10.1038/srep28581.

Brakensiek, D.L, Osborn, H.B., Rawls, W.J., 1979. Field Manual for Research in Agricultural Hydrology (Agriculture Handbook No. 224). U.S. Department of Agriculture, Washington, DC.

Briggs, M.A., Lautz, L.K., Hare, D.K., González-Pinzón, R., 2013. Relating hyporheic fluxes, residence times, and redox-sensitive biogeochemical processes upstream of beaver dams. Freshwater Sci. 32 (2), 622-641. http://dx.doi.org/10.1899/12-110.1.

Brunner, W.G., 2014. Using HEC-RAS for Dam Break Studies (Rep. TD-39). U.S. Army Corps of Engineers Hydrologic Engineering Center (HEC), Davis, CA.

Collins, B.D., Montgomery, D.R., 2002. Forest development, wood jams, and restoration of floodplain rivers in the Puget Lowland, Washington. Restor. Ecol. 10 (2), 237-247. http://dx.doi.org/10.1046/j.1526-100X.2002.01023.x.

Covino, T., 2017. Hydrologic connectivity as a framework for understanding biogeochemical flux through watersheds and along fluvial networks. Geomorphology 277, 133-144. http://dx.doi.org/10.1016/j.geomorph.2016.09.030.

Crispell, J.K., Endreny, T.A., 2009. Hyporheic exchange flow around constructed inchannel structures and implications for restoration design. Hydrol. Process. 23 (8), 1158-1168. http://dx.doi.org/10.1002/hyp.7230.

Curran, J.H., Wohl, E.E., 2003. Large woody debris and flow resistance in step-pool channels, Cascade Range, Washington. Geomorphology 51 (1), 141-157. http://dx. doi.org/10.1016/S0169-555X(02)00333-1.

Darby, S.E., 1999. Effect of riparian vegetation on flow resistance and flood potential Journal of Hydraulic Engineering 125 (5), 443-454.

Davidson, S.L., Eaton, B.C., 2013. Modeling channel morphodynamic response to variations in large wood: implications for stream rehabilitation in degraded watersheds. Geomorphology 202, 59-73. http://dx.doi.org/10.1016/j.geomorph.2012.10.005.

Development Core Team, R., 2017. R: A language and Envrionment for Statistical Computing. R Foundation for Statistical Computing, Vienna, Austria.

Dixon, S.J., Sear, D.A., 2014. The influence of geomorphology on large wood dynamics in a low gradient headwater stream. Water Resour. Res. 50 (12), 9194-9210. http://dx. doi.org/10.1002/2014WR015947.

Dolloff, C.A., Warren Jr., M.L., 2003. Fish relationships with large wood in small streams. Am. Fish. Soc. Symp. 37 (179-193), 2003.

Ensign, S.H., McMillan, S.K., Thompson, S.P., Piehler, M.F., 2006. Nitrogen and phosphorus attenuation within the stream network of a coastal, agricultural watershed. J. Environ. Qual. 35 (4), 1237-1247. http://dx.doi.org/10.2134/jeq2005.0341.

Forshay, K.J., Stanley, E.H., 2005. Rapid nitrate loss and denitrification in a temperate river floodplain. Biogeochemistry 75 (1), 43-64. http://dx.doi.org/10.1007/s10533004-6016-4.

Grnell, A.M., Piegay, H., Swanson, F.J., Gregory, S.V., 2002. Large wood and fluvial processes. Freshw. Biol. 47 (4), 601-619. http://dx.doi.org/10.1046/j.1365-2427. 2002.00916.x.

Gurnell, A., 2012. Fluvial geomorphology: wood and river landscapes. Nat. Geosci. 5 (2), 93. http://dx.doi.org/10.1038/ngeo1382.

Hafs, A.W., Harrison, L.R., Utz, R.M., Dunne, T., 2014. Quantifying the role of woody debris in providing bioenergetically favorable habitat for juvenile salmon. Ecol. Model. 285, 30-38. http://dx.doi.org/10.1016/j.ecolmodel.2014.04.015.

Harvey, J., Gooseff, M., 2015. River corridor science: hydrologic exchange and ecological consequences from bedforms to basins. Water Resour. Res. 51 (9), 6893-6922. http://dx.doi.org/10.1002/2015WR017617.

Henderson, F.M., 1966. Open Channel Flow. Macmillan, New York City, NY.

Hession, W.C., Curran, J.C., 2013. The impacts of vegetation on roughness in fluvial systems. In: Shroder, J.F. (Ed.), Treatise on Geomorphology. Academic Press, San Diego, pp. 75-93. http://dx.doi.org/10.1016/B978-0-12-374739-6.00323-7.

Hester, E.T., Doyle, M.W., 2008. In-stream geomorphic structures as drivers of hyporheic exchange. Water Resour. Res. 44 (3). http://dx.doi.org/10.1029/2006WR005810.

Hester, E.T., Hammond, B., Scott, D.T., 2016b. Effects of inset floodplains and hyporheic exchange induced by in-stream structures on nitrate removal in a headwater stream. Ecol. Eng. 97, 452-464. http://dx.doi.org/10.1016/j.ecoleng.2016.10.036.

Hester, E.T., Guth, C.R., Scott, D.T., Jones, C.N., 2016a. Vertical surface water-groundwater exchange processes within a headwater floodplain induced by experimental floods. Hydrol. Process. 30 (21), 3770-3787. http://dx.doi.org/10.1002/hyp.10884.

Horritt, M.S., Bates, P.D., 2001. Predicting floodplain inundation: raster-based modelling versus the finite-element approach. Hydrol. Process. 15 (5), 825-842. http://dx.doi. org/10.1002/hyp.188.

Jarrett, R.D., 1984. Hydraulics of high-gradient streams. J. Hydraul. Eng. 110 (11), 1519-1539. http://dx.doi.org/10.1061/(ASCE)0733-9429(1984)110:11(1519).

Jeffries, R., Darby, S.E., Sear, D.A., 2003. The influence of vegetation and organic debris on flood-plain sediment dynamics: case study of a low-order stream in the New Forest, England. Geomorphology 51 (1-3), 61-80. http://dx.doi.org/10.1016/S0169555X(02)00325-2.

Johnson, L.B., Breneman, D.H., Richards, C., 2003. Macroinvertebrate community 
structure and function associated with large wood in low gradient streams. River Res. Appl. 19 (3), 199-218. http://dx.doi.org/10.1002/rra.712.

Jones, C.N., Scott, D.T., Edwards, B.L., Keim, R.F., 2014. Perirheic mixing and biogeochemical processing in flow-through and backwater floodplain wetlands. Water Resour. Res. 50 (9), 7394-7405. http://dx.doi.org/10.1002/2014WR015647.

Jones, C.N., Scott, D.T., Guth, C., Hester, E.T., Hession, W.C., 2015. Seasonal variation in floodplain biogeochemical processing in a restored headwater stream. Environ. Sci. Technol. 49 (22), 13190-13198. http://dx.doi.org/10.1021/acs.est.5b02426.

Kail, J., Hering, D., Muhar, S., Gerhard, M., Preis, S., 2007. The use of large wood in stream restoration: experiences from 50 projects in Germany and Austria. J. Appl. Ecol. 44 (6), 1145-1155. http://dx.doi.org/10.1111/j.1365-2664.2007.01401.x.

Karr, J.R., Dudley, D.R., 1981. Ecological perspective on water quality goals. Environ. Manage. 5 (1), 55-68. http://dx.doi.org/10.1007/BF01866609.

Keaton, J.N., Messinger, T., Doheny, E.J., 2005. Development and Analysis of Regional Curves for Streams in the Non-urban Valley and Ridge Physiographic Province, Maryland, Virginia, and West Virginia. US Department of the Interior, US Geological Survey.

Keys, T.A., Jones, C.N., Scott, D.T., Chuquin, D., 2016. A cost-effective image processing approach for analyzing the ecohydrology of river corridors. Limnol. Oceanogr. Methods 14 (6), 359-369. http://dx.doi.org/10.1002/lom3.10095.

Kossieris, P., Makropoulos, C., Onof, C., Koutsoyiannis, D., 2016. A rainfall disaggregation scheme for sub-hourly time scales: coupling a Bartlett-Lewis based model with adjusting procedures. J. Hydrol. http://dx.doi.org/10.1016/j.jhydrol.2016.07.015.

Krause, S., Klaar, M.J., Hannah, D.M., Mant, J., Bridgeman, J., Trimmer, M., ManningJones, S., 2014. The potential of large woody debris to alter biogeochemical processes and ecosystem services in lowland rivers. Wiley Interdiscipl. Rev. Water 1 (3), 263-275. http://dx.doi.org/10.1002/wat2.1019.

Lagasse, P.F., Zevenbergen, L.W., Spitz, W.J., Arneson, L.A., 2012. Stream Stability at Highway Structures (Rep. FHWA-HIF-12-004). Federal Highway Administration, Washington, DC.

Levine, R., Meyer, G.A., 2014. Beaver dams and channel sediment dynamics on Odell Creek, Centennial Valley, Montana, USA. Geomorphology 205, 51-64. http://dx.doi. org/10.1016/j.geomorph.2013.04.035.

Marcus, W.A., Roberts, K., Harvey, L., Tackman, G., 1992. An evaluation of methods for estimating Manning's $n$ in small mountain streams. Mt. Res. Dev. 227-239. http://dx. doi.org/10.2307/3673667.

Matheson, A., Thoms, M., Reid, M., 2017. Does reintroducing large wood influence the hydraulic landscape of a lowland river system? Geomorphology 292, 128-141. http://dx.doi.org/10.1016/j.geomorph.2017.03.035.

May, C.L., Gresswell, R.E., 2003. Large wood recruitment and redistribution in headwater streams in the southern Oregon Coast Range USA. Can. J. For. Res. 33 (8), 1352-1362. http://dx.doi.org/10.1139/x03-023.

McFarland, A., Hauck, L.M., 1999. Relating agricultural land uses to in-stream stormwater quality. J. Environ. Qual. 28 (3), 836-844. http://dx.doi.org/10.2134/ jeq1999.00472425002800030014x.

McMillan, S.K., Piehler, M.F., Thompson, S.P., Paerl, H.W., 2010. Denitrification of nitrogen released from senescing algal biomass in coastal agricultural headwater streams. J. Environ. Qual. 39 (1), 274-281. http://dx.doi.org/10.2134/jeq2008. 0438.

Montgomery, D.R., Collins, B.D., Buffington, J.M., Abbe, T.B., 2003. Geomorphic effects of wood in rivers. Paper presented at American Fisheries Society Symposium, Bethesda, MD.

Mueller Price, J.S., Baker, D.W., Bledsoe, B.P., 2016. Effects of passive and structural stream restoration approaches on transient storage and nitrate uptake. River Res. Appl. 32 (7), 1542-1554. http://dx.doi.org/10.1002/rra.3013.

Mulholland, P.J., Helton, A.M., Poole, G.C., Hall, R.O., Hamilton, S.K., Peterson, B.J., et al., 2008. Stream denitrification across biomes and its response to anthropogenic nitrate loading. Nature 452 (7184), 202. http://dx.doi.org/10.1038/nature06686.

Noe, G.B., Hupp, C.R., 2009. Retention of riverine sediment and nutrient loads by coastal plain floodplains. Ecosystems 12 (5), 728-746. http://dx.doi.org/10.1007/s10021009-9253-5.

Pappenberger, F., Beven, K., Horritt, M., Blazkova, S., 2005. Uncertainty in the calibration of effective roughness parameters in HEC-RAS using inundation and downstream level observations. J. Hydrol. 302 (1), 46-69. http://dx.doi.org/10.1016/j.jhydrol. 2004.06.036.

Parker, C., Henshaw, A.J., Harvey, G.L., Sayer, C.D., 2017. Reintroduced large wood modifies fine sediment transport and storage in a lowland river channel. Earth Surf. Proc. Land. http://dx.doi.org/10.1002/esp.4123.

Piégay, H., Gurnell, A.M., 1997. Large woody debris and river geomorphological pattern: examples from SE France and S. England. Geomorphology 19 (1-2), 99-116. http:// dx.doi.org/10.1016/S0169-555X(96)00045-1.

Pollock, M.M., Beechie, T.J., Wheaton, J.M., Jordan, C.E., Bouwes, N., Weber, N., Volk, C., 2014. Using beaver dams to restore incised stream ecosystems. Bioscience 64 (4), 279-290. http://dx.doi.org/10.1093/biosci/biu036.

Quiroga, V.M., Kure, S., Udo, K., Mano, A., 2016. Application of 2D numerical simulation for the analysis of the February 2014 Bolivian Amazonia flood: application of the new HEC-RAS version 5. RIBAGUA-Revista Iberoamericana del Agua 3 (1), 25-33. http:// dx.doi.org/10.1016/j.riba.2015.12.001.

Rafferty, M., 2013. Development of a Computational Design Tool for Evaluating the Stability of Large Wood Structures Proposed for Stream Enhancement (Master's Thesis). Colorado State University, Fort Collins, Colorado.

Rana, S.M., Scott, D.T., Hester, E.T., 2017. Effects of in-stream structures and channel flow rate variation on transient storage. J. Hydrol. 548, 157-169. http://dx.doi.org/ 10.1016/j.jhydrol.2017.02.049.

Records, R.M., Wohl, E., Arabi, M., 2016. Phosphorus in the river corridor. Earth Sci. Rev. 158, 65-88. http://dx.doi.org/10.1016/j.earscirev.2016.04.010.

Rodriguez-Iturbe, I., Cox, D.R., Isham, V., 1987. Some models for rainfall based on stochastic point processes. Proc. R. Soc. London A 410 (18392), 69-288. http://dx.doi. org/10.1098/rspa.1987.0039.

Ruiz-Villanueva, V., Bladé Castellet, E., Díez-Herrero, A., Bodoque, J.M., Sánchez-Juny, M., 2014. Two-dimensional modelling of large wood transport during flash floods. Earth Surf. Proc. Land. 39 (4), 438-449. http://dx.doi.org/10.1002/esp.3456.

Ruiz-Villanueva, V., Piégay, H., Gurnell, A.A., Marston, R.A., Stoffel, M., 2016. Recen advances quantifying the large wood dynamics in river basins: new methods and remaining challenges. Rev. Geophys. 54 (3), 611-652. http://dx.doi.org/10.1002/ 2015RG000514.

Schmocker, L., Weitbrecht, V., 2013. Driftwood: risk analysis and engineering measures. J. Hydraul. Eng. 139 (7), 683-695. http://dx.doi.org/10.1061/(ASCE)HY.19437900.0000728

Scott, D.T., Keim, R.F., Edwards, B.L., Jones, C.N., Kroes, D.E., 2014. Floodplain biogeochemical processing of floodwaters in the Atchafalaya River Basin during the Mississippi River flood of 2011. J. Geophys. Res. Biogeosci. 119 (4), 537-546. http:// dx.doi.org/10.1002/2013JG002477.

Sear, D.A., Millington, C.E., Kitts, D.R., Jeffries, R., 2010. Logjam controls on channel: floodplain interactions in wooded catchments and their role in the formation of multi-channel patterns. Geomorphology 116 (3-4), 305-319. http://dx.doi.org/10. 1016/j.geomorph.2009.11.022.

Smith, M.J., Asal, F.F.F., Priestnall, G., 2004. The use of photogrammetry and lidar for landscape roughness estimation in hydrodynamic studies. Int. Arch. Photogramm. Remote Sens. Spatial Inf. Sci. 35 (B3), 714-719.

Soulsby, C., Dick, J., Scheliga, B., Tetzlaff, D., 2017. Taming the Flood-how far can we go with trees? Hydrol. Process. http://dx.doi.org/10.1002/hyp.11226.

Straatsma, M.W., Baptist, M.J., 2008. Floodplain roughness parameterization using airborne laser scanning and spectral remote sensing. Remote Sens. Environ. 112 (3), 1062-1080. http://dx.doi.org/10.1016/j.rse.2007.07.012.

Vitousek, P.M., Aber, J.D., Howarth, R.W., Likens, G.E., Matson, P.A., Schindler, D.W., et al., 1997. Human alteration of the global nitrogen cycle: sources and consequences. Ecol. Appl. 7 (3), 737-750.

Wegener, P., Covino, T., Wohl, E., 2017. Beaver-mediated lateral hydrologic connectivity, fluvial carbon and nutrient flux, and aquatic ecosystem metabolism. Water Resour. Res. 53 (6), 4606-4623. http://dx.doi.org/10.1002/2016WR019790.

Westbrook, C.J., Cooper, D.J., Baker, B.W., 2006. Beaver dams and overbank floods influence groundwater-surface water interactions of a Rocky Mountain riparian area. Water Resour. Res. 42 (6). http://dx.doi.org/10.1029/2005WR004560.

Wilford, D.J., Sakals, M.E., Innes, J.L., Sidle, R.C., Bergerud, W.A., 2004. Recognition of debris flow, debris flood and flood hazard through watershed morphometrics. Landslides 1 (1), 61-66. http://dx.doi.org/10.1007/s10346-003-0002-0.

Wohl, E., 2013. Floodplains and wood. Earth Sci. Rev. 123, 194-212. http://dx.doi.org/ 10.1016/j. earscirev.2013.04.009.

Wohl, E., Goode, J.R., 2008. Wood dynamics in headwater streams of the Colorado Rocky Mountains. Water Resour. Res. 44 (9). http://dx.doi.org/10.1029/2007WR006522.

Wohl, E., Bledsoe, B.P., Fausch, K.D., Kramer, N., Bestgen, K.R., Gooseff, M.N., 2016. Management of large wood in streams: an overview and proposed framework for hazard evaluation. J. Am. Water Resour. Assoc. 52 (2), 315-335. http://dx.doi.org/ $10.1111 / 1752-1688.12388$.

Woltemade, C.J., 1994. Form and process: fluvial geomorphology and flood-flow interaction, Grant River, Wisconsin. Ann. Assoc. Am. Geogr. 84 (3), 462-479. http://dx. doi.org/10.1111/j.1467-8306.1994.tb01870.x. 